\title{
Conceito e classificação da propriedade na pós- modernidade: a era das propriedades especiais
}

\author{
José Isaac Pilati ${ }^{1}$
}

\begin{abstract}
Resumo. Enfoca-se a propriedade especial constitucional, que se destaca da propriedade comum corpórea tradicional (dos códigos), afirmando-se como base das transformações do Direito, na Pós-Modernidade.
\end{abstract}

Palavras-chave: Propriedade especial constitucional. Pós-modernidade.

\begin{abstract}
The constitutional special property is the focus, that stands out of the traditional corporal common property (of the codes), being affirmed as base of the transformations of the Right, in the Powder-modernity.
\end{abstract}

Keywords: Constitucional especial property. Powder-modernity.

\section{Introdução}

A propriedade é a instituição central da civilização, não só por constituir o conjunto básico de valores ${ }^{2}$ - uma mentalidade, como diz Grossi $^{3}$ - com que se orientam e pautam pessoas e coisas, mas também por determinar e materializar a estrutura com que historicamente se regem e reproduzem as relações de Estados e de indivíduos e de Sociedades.

1 Professor do Curso de Pós-graduação em Direito da Universidade Federal de Santa Catarina. Trabalho defendido no II Encontro Temático do Projeto Casadinho UFC/UFSC 2009, ampliado e transformado em artigo.

2 REALE, Miguel. Introdução à filosofia. São Paulo: Saraiva, 1994, p. 181 et seq. Toda cultura é histórica e não pode ser concebida fora da história. Em cada tempo predomina um valor em relação a outros. Os valores não estão isolados uns dos outros, mas se ordenam de forma gradativa, hierarquizando-se entre subordinantes e subordinados, ou fundamentais e secundários. A ética proprietária assenta no ter a Moral individual e social (Direito) do bem fundamental, que é a propriedade.

3 GROSSI, Paolo. La propiedad e las propiedades: un análisis histórico. Traducción de Angel M. López y López. Madri: Civitas, 1992. 
$\mathrm{Na}$ pós-modernidade ${ }^{4}$ confrontam-se dois modelos: o da proprieté napoleônica, reproduzida no art. 1228 do CCB - criticada pelo pioneiro discurso de função social de Duguit; e o das propriedades especiais constitucionais de 1988, que despontam sob a égide jurídica do coletivo e a aura política da participação.

A modernidade e as codificações trabalharam com um conceito estrito de propriedade, limitado ao âmbito das coisas corpóreas; o capital financeiro correu por fora desse âmbito, num buraco-negro jurídico que o punha a salvo de qualquer enquadramento ou compromisso de função social. Já a pós-modernidade deverá trabalhar com um conceito amplo de propriedade, ${ }^{5}$ incluindo todo poder patrimonial oponível ao grupo social. Isso coloca ao alcance da função social todo o poder, individual e social, seja ele político, econômico, de que natureza for. Com isso não é o conceito de propriedade que se modifica, mas o arcabouço, o paradigma.

Rodotá $^{6}$ diz que a propriedade carrega um enigma, perante a desigualdade social renitente, que o Estado e os instrumentos da ordem jurídica não conseguem resolver. Este é o ponto que importa: até aonde vai

4 RUSSO, Eduardo Angel. Teoria general del derecho: en la modernidad y en la posmodernidad. Buenos Aires: Abeledo-Perrot, [1995?], p. 317 et seq. La posmodernidad parece ser, entre otras cosas, el lugar para las nuevas utopías. Desde el antológico 'mayo francés' pedir lo imposible se tiene por uma forma de hacer que o imposible sea real. Na p. 318 alerta: La posmodernidad es, en primer lugar, una moda. Es decir, algo que alguien crea y que muchos usan sin saber de que se trata. Uma moda que alguém cria $\mathrm{e}$ que muitos utilizam sem saber de que se trata. DIAS, Maria da Graça dos Santos. Direito e pós-modernidade. In: DIAS, M. G. S; MELO, O. F; SILVA, M.M. Política jurídica e pós-modernidade. Florianópolis: Conceito, 2009, p. 11-34, destaca que, na modernidade, o parlamento representa o povo e o governo é das leis, não dos homens.

5 MACKELDEY, F. Elementos del derecho romano. 4 ed. Madrid: L. López, 1886, p. 151, chama a atenção, como romanista, para a propriedade em sentido amplo, que inclui toda a fortuna e tudo o que pertence a alguém; a propriedade de bens corpóreos é propriedade em sentido estrito. As propridades especiais da pós-modernidade devem devolver importância à propriedade en el sentido extenso de la palabra.

6 RODOTÁ, Stefano. Il terribile diritto: studi sulla proprietà privada. Bolonha: Il Mulino, 1990, inaugura a obra referindo a questão proprietária, que sempre se propõe, mas que não (ou nunca) se soluciona, restando intacto perante nós l'enigma della proprietà (p. 15). Pode-se dizer o mesmo da corrupção, que é uma fraude quanto aos méritos proprietários. São, portanto, dois desafios à pós-modernidade: a desigualdade e a corrupção. 
o mérito proprietário? Locke $^{7}$ justifica a apropriação com fundamento no trabalho, porém não para açambarcar a terra e sim para usufruirmos. Assim é de início, arremata: Direito e conveniência andando juntos, sendo inútil, bem como desonesto, tomar demasiado, ou mais do que o necessário. $\mathrm{O}$ dinheiro também se justificaria nessa linha: como meio de tornar durável (com a troca) o perecível, pois o desperdício é igualmente condenável.

O liberalismo de Locke é preciso não só nesse aspecto, do mérito e dos limites da propriedade; ele baseia a relação de poder não no Estado como Hobbes; ${ }^{8}$ mas num estado de natureza anterior, que é de plena liberdade. Liberdade de indivíduos proprietários, que criam o Estado e participam do governo. ${ }^{9}$ As propostas de reforma que não observam este princípio basilar - da propriedade como instituição e substância - partem da perspectiva de que Estado e Direito são exteriores à propriedade; com isso tendem a serem conservadoras, porque o poder do Estado situa-se no lado da reação, enquanto o proprietário está no campo da ação, em tempo real.

A crise de hoje, sobretudo a ecológica, é reflexo de um novo momento da propriedade em sentido amplo: as velhas formas, jurídica e política, já não correspondem à substância. Esse descompasso entre substância e forma, confunde os eruditos do nosso tempo, que apesar do talento e da aplicação da maioria, perderam o senso de direção da força. ${ }^{10}$ O método que compartilham de modo geral como paradigma enreda-os na massa falida da modernidade, e eles pretendem solucionar a obsolescência

7 LOCKE, John. Tratado sobre o governo civil. Tradução de Renato Janine Ribeiro. São Paulo: Martins Fontes, 1998, p. 406 et seq. Como os homens podem vir a ter propriedade, se Deus deu a terra à humanidade em comum? Cada homem tem uma propriedade em sua própria pessoa. O trabalho de seu corpo e a obra de suas mãos, pode-se dizer, são propriamente dele (p. 409).

8 HOBBES, Thomas. Leviatã: ou a matéria, forma e poder de um estado eclesiástico e civil. Tradução de Rosina D’Angina. São Paulo: Ícone, 2000.

9 PEREIRA, Ascísio dos Reis. A moral liberal como processo educativo no pensamento político de John Locke. In: CANDIDO, Celso; CARBONARA, Vanderlei. Filosofia e ensino: um diálogo transdisciplinar. Ijuí: Unijuí, 2004, p. 153-167. Disponível em: <www. espaçoacademico.com.br>. Acesso em: 20 abr. 2009.

10 Parafraseia-se SAVIGNY, Friedrich Karl Von. Metodologia jurídica. Tradução de Heloísa da Graça Buratti. São Paulo: Rideel, 2005, p. 15. 
jurídica com paliativos da velha ordem superada. Como se fosse possível tutelar o coletivo com instrumentos do $\mathrm{CPC}$ e sem rever o arcabouço institucional.

A realidade é que se está a manter uma ordem jurídica que se tornou inadequada à tutela dos interesses fundamentais da civilização e da espécie humana. A própria $\mathrm{ONU}{ }^{11}$ anuncia a iminência da tragédia global por obra do homem; ${ }^{12}$ porém, não cuida da causa primeira que é a inaptidão do Estado autocrático, do qual ela mesma é a grande voz. Inaptidão de um sistema que não tem solução para a crise do modelo de desenvolvimento, que esgotou um planeta finito. Um sistema cujo conceito de propriedade é superado e exige nova conformação das instituições políticas e jurídicas; que resgate o coletivo como condição essencial do equilíbrio proprietário.

Porém, não significa romper com o princípio da corporiedade do Código Civil; e sim resgatar o arcabouço conceitual e estrutural da propriedade como instituto. Não é o caso de discutir se a propriedade é um fenômeno construído, histórico - na expressão de Nietzsche $^{13}$

11 Os alertas são do Painel Intergovernamental sobre Mudança Climática - IPCC posto em ação pela ONU em 1988.

12 Sobre o efeito estufa, ver BRASIL, Ministério da Ciência e Tecnologia. Efeito estufa e a convenção sobre a mudança do clima. Disponível em: <www.dominiopublico.gov.br>. Acesso em: 30 jan. 2008. O excesso de emissões antrópicas, especialmente de dióxido de carbono, mas também de mano e óxido nitroso, podem provocar mudança permanente no clima, imprimindo novos padrões no regime de ventos, pluviosidade e circulação dos oceanos - com possíveis consequências catastróficas para a humanidade, como o aumento do nível do mar. Nos últimos 70 anos, registrou-se aumento médio de $0,6^{\circ} \mathrm{C}$ na temperatura da superfície do globo.

13 FOUCAULT, Michel. A verdade e as formas jurídicas. Tradução de Roberto Cabral de melo Machado e Eduardo Jardim Morais. Rio de Janeiro: Nau, 1999 Texto que reproduz um ciclo de conferências realizado no Rio de Janeiro em maio de 1973, usou do pensamento de Nietzsche para questionar os esteios do pensamento ocidental, destacando a dimensão histórica do sujeito do conhecimento e da própria verdade; não teriam origem metafísica (Ursprung), mas seriam coisas inventadas, fabricadas (Erfindung). O conhecimento, no fundo, não faz parte da natureza humana. É a luta, o combate, o resultado do combate e consequentemente o risco e o acaso que vão dar lugar ao conhecimento. O conhecimento não é instintivo é contra-instintivo, assim como ele não é natural, é contra-natural (p. 17). E em seguida: Eis a grande ruptura com o que havia sido tradição da filosofia ocidental, quando até mesmo Kant foi o primeiro a dizer explicitamente que as condições de experiência e do 
contranatural - ou, se é eterno, fazendo parte da natureza humana. Ela incorpora e institucionaliza relação de luta, de poder, de dominação e subserviência. Não é campo neutro, nem objeto estático. O grande desafio do Direito pós-moderno, em sua função mediadora, consiste, basicamente, em definir-lhe estrutura e conceito em que o coletivo tenha o mesmo peso dado ao individual.

Nesta tarefa, o sistema romano de propriedade é contraponto de inspiração insuperável para o raciocínio pós-moderno; porque a propriedade romana era exercida sob o manto da democracia participativa, e não representativa. O público-privado romano é diferente do desenho da modernidade, justamente por isso, porque funciona sem a mediação de um ente como o Estado Moderno, separado deles. O dominium romano significa submissão de pessoas e bens ao pater familias, não a um proprietário individual, e as relações se travam em foros de um condomínio de romanos pater familias, que partilham o coletivo no plano religioso, jurídico e político.

Engels $^{14}$ é um caso clássico de leitura moderna equivocada do modelo romano. O brilhante parceiro de Marx não consegue visualizar o coletivo não estatal de Roma e adota como método contrapor: à propriedade a tribo primitiva, de constituição gentílica e base familiar. O seu viés é de extinção da propriedade e perecimento de um Estado de classes; e com esses olhos examina a realidade romana, na qual identifica, por

objeto da experiência eram idênticos. Nietzsche pensa ao contrário, que entre conhecimento e mundo a conhecer há tanta diferença quanto entre conhecimento e natureza humana (p. 17 e 18). Quando Nietzsche estabelece ruptura ente conhecimento e coisas (no sentido de que não há harmonia prévia entre o conhecimento e as coisas a conhecer) e ruptura entre conhecimento e instintos (no sentido de que o conhecimento é resultado dos instintos, mas não é nem deriva diretamente dos instintos), está afirmando, por via de consequência, que a propriedade - como conhecimento aplicado que é, também é contra-natural. É também relação de poder, de dominação e de subserviência, historicamente construída.

14 ENGELS, Friedrich. A origem da família, da propriedade privada e do Estado. Tradução de Leandro Konder. 14. ed. Rio de Janeiro: Bertrand Brasil, 1997. É um clássico nessa abordagem. A tribo teria entrado em colapso às primeiras manifestações do trabalho, da acumulação, da vida econômica ativa, até o salto dialético vivenciado pela Grécia Antiga, onde se manifesta pela primeira vez o embrião da Sociedade estatal, com leis territoriais, poder de polícia separado dos habitantes e nas mãos de um ente abstrato, que seria o Estado. 
sua conta, a existência de: súditos do Estado; terras conquistadas pelo Estado; autêntica constituição de Estado, ${ }^{15}$ noções a que é levado pelo direcionamento teleológico do seu método, que persegue a eliminação da luta de classes. ${ }^{16}$

Sob esse ângulo de visão e de construção teórica, Engels está vendo Roma com os olhos da modernidade e seu paradigma: ${ }^{17}$ como se tivesse tido, como forma de governo, uma república representativa e autocrática; como se não tivesse sido a Roma da civitas - dos romanos com comitia, magistraturas ${ }^{18}$ e senado - e sim a república de Roma, pessoa jurídica separada dos cidadãos, manipulada por uma classe dominante. Nessa linha, seu direcionamento parece não ser no rumo de um coletivo de equilíbrio, de res populi, a ser restabelecido sob as garantias do Estado Democrático de Direito pós-moderno; e sim de um coletivo totalitário e utópico.

O prejuízo desse tipo de leitura das instituições romanas clássicas como Estado Antigo - é inevitável: perde-se o elemento de equilíbrio entre

15 ENGELS, Friedrich. A origem da família, da propriedade privada e do Estado, p. 143, 145. Referindo-se a latinos e peregrinos que viviam em Roma: Todos estes novos súditos do Estado (deixando de lado a questão dos 'clientes') viviam fora das antigas gens, cúrias e tribos [omissis]. Mais adiante: Não podiam [omisis] beneficiar-se das terras conquistadas pelo Estado. E na p. 145: Uma nova constituição a substituiu, uma autêntica constituição de Estado [omissis] A força pública [omissis] também, se opunha à classe dita proletária, excluída do serviço militar e impedida de usar armas. Como pode o autor utilizar categorias modernas em tal contexto, como se as realidades fossem simétricas?

16 MARX, K; ENGELS, F. Manifesto do Partido Comunista. Tradução de Pietro Nassetti. São Paulo: Martin Claret, 2003. A história de todas as sociedades que existiram até hoje é a história de lutas de classes.

17 Marx, evidentemente, comunga dessa ideia, fazendo alusão a: A auto-importância da esfera política - o engano do Estado Antigo. MARX, K; ENGELS, F. A ideologia alemã. Tradução de José Carlos Bruni; Marco Aurélio Nogueira. 10. ed. São Paulo: Hucitec, 1996, p. 130.

18 Basta observar como os plebeus posicionaram-se na seccessio plebis: a criação do tribunato colocou-os no plano de igualdade (conferindo-lhes direito de veto e instância de comitia plebis), sem os transformar em patrícios. A excelência das instituições reside nisso: estarem à altura dos conflitos de sua época, resolvê-los e não eliminá-los. Nessa linha é esclarecedor o texto de TAFARO, Sebastiano. La herencia de los tribuni plebis. Traducido por Carla Amans. Buenos Aires [2008?], digit. 
particular/público/coletivo. Se a modernidade apropriou-se do coletivo em favor do particular, a pós-modernidade não pode ir para o outro extremo: anular o particular num coletivo de feição estatal. Pois tal tese chega, por linha transversa e ironicamente, ao mesmo resultado que combate, porque deságua num coletivo autocrático, com a mesma feição da modernidade. A pós-modernidade deverá instituir um sistema estruturado na tríplice dimensão que Roma ensinou: de coletivo x privado x estatal. ${ }^{19}$

A dimensão de república participativa que Roma vivenciou e que a pós-modernidade retoma no plano constitucional, repõe a questão a ser dialeticamente sintetizada: não eleminar a velha propriedade e o velho Estado, mas resgatá-los em plano superior, redefinindo-os. Reestruturá-los em nova sinergia como elementos da nova ordem social. Nova ordem que irá fundamentar e legitimar a propriedade na justiça do mérito, de capital e trabalho, em novo suum cuique tribuere, ${ }^{20}$ baseado no equilíbrio entre as esferas distintas: do privado (indivíduo), do público (Estado) e do coletivo (Sociedade). Mirando-se no espelho da Antiguidade, recompor a face.

19 AAntiguidade romana plasma nas instituições políticas os dois elementos fundamentais: o bem do indivíduo e o bem do todo, naquilo que o bem social é condição do bem de cada qual. O bem, visto como valor social, é o que chamamos propriamente de justo, e constitui o valor fundante do Direito. REALE, Miguel. Introdução à filosofia. São Paulo: Saraiva, p. 209. A modernidade encarna e inclui, neste plano fundamental, um terceiro elemento, que é o Estado separado dos indivíduos; confere autonomia ao espaço de imperium, que era conferido às magistraturas romanas. Por isso, quando Marx e Engels falam de Estado Antigo, equiparado em função ao Estado Moderno (da e na luta de classes), laboram num método incompatível com a proposta de resgate do coletivo (pós-moderno) deste livro.

20 Dos três princípios de Ulpiano (D. 1,1,10,1 e I, 1,1,3) - viver honestamente (honeste vivere), não lesar outrem (alterum non laedere) e dar a cada um o que é seu (suum cuique tribuere) - este último tem uma tradução, modernamente, que pode não condizer com o exato sentido original dos romanos. Tribuo, tribuere, como verbo transitivo, tem sentido próprio de dividir entre as tribos; daí, na língua comum, distribuir, repartir, dividir; de onde: atribuir, conceder, dar, destinar, imputar. Como intransitivo: ter consideração ou condescendência para com. FARIA, Ernesto. Dicionário escolar latino-português. 4 ed. Brasília: Ministério da Educação e Cultura, 1967, p. 1018. Dar a cada um o que lhe pertence está no plano individualista moderno; atribui a cada um o que lhe é devido por direito objetivo. E se a ideia for a de imputar direitos coletivos? Direitos sociais fundamentais? Ramos, por exemplo, critica tais princípios pela sua vagueza e a imprecisão de limites entre Direito e Moral. Será que ele tem razão nesse lugar-comum (próprio da modernidade)? RAMOS, J. Arias. Derecho romano: parte general, derechos reales, p. 29. 


\section{Propriedade comum e especial: dois perfis e um paradigma a construir}

O constitucionalismo brasileiro contemporâneo consagra dois sistemas, que se fundem na pós-modernidade; o da propriedade comum, que possui princípios e regras próprias e representa a grande conquista moderna da liberdade individual perante o Estado, o público, e os demais indivíduos; e o outro, materializado nas propriedades especiais, que se pautam por outras normas de exercício e tutela, orientadas pelo coletivo e pela função social. As propriedades de uma e de outra categoria possuem titular, objeto, exercício e tutela diferenciados, mas convivem em harmonia, num sistema, assim, muito mais complexo do que o romano.

\subsection{A propriedade comum}

A propriedade comum é a de caráter dominial, regida pelo Código Civil (art. 1228), que se contrapõe como sistema, tradicionalmente, à propriedade pública, regida pelo direito administrativo. Estruturase e classifica-se pelas categorias tradicionais: móvel e imóvel, plena e restrita, perpétua e resolúvel. É avessa ao condomínio, que tolera como uma situação transitória; tem na posse um instrumento avançado de defesa (interditos) e nas ações petitórias (reivindicatória, negatória) o instrumento adequado de tutela; e desdobra-se em direitos reais limitados de gozo (que se tutelam por interditos e ações confessórias) e de garantia (créditos privilegiados).

Atua reduzindo o universo subjetivo aos dois interlocutores: indivíduo proprietário e Estado pessoa. No plano do objeto, restringe os bens jurídicos às duas categorias: públicos e privados. À base desses elementos, o direito subjetivo da dominialidade submete os objetos corpóreos à lógica proprietária, em substância, essência e erga omnes, com as limitações da lei; ou seja, outorgando ao Direito a função limitada de forma, a serviço da liberdade que nasce do ter, e que privilegia as relações econômicas. Por isso, o saber jurídico da modernidade tende a ser assunto de leis e de especialistas, a operar por subsistemas que funcionam por subsunção. 
Tende-se a reduzir o Direito à lei, ao monismo estatal, dando plena liberdade ao proprietário, que pode fazer tudo o que a lei não proíbe, pois o Direito diz, apenas, como e não $o$ que fazer. Nesse diapasão, a jurisdição é monopólio estatal, que substituindo as partes diz o direito declarando quem tem razão, sem preocupação, em termos de sistema, com o resultado efetivo do processo. Vale dizer, um sistema que abstrai da alternativa que não seja autocrática; ao contrário, o paradigma costuma ver com desconfiança qualquer proposta participativa, que transfira às partes a soberania da decisão.

Imperando hegemonicamente esse modelo da Propriedade Moderna, o Estado tende a desautorizar qualquer centro de poder que fuja desse padrão codificado; monopolizando a produção jurídica, procurou sempre reduzir as formas de propriedade privada a uma só, a individual. Essa tendência pode ser observada em algumas formas arcaicas de propriedade coletiva, que resistiram ao binômio de estatismo e individualismo proprietário, tanto em Portugal com os baldios, como em Espanha com os bienes comunales, em França com os biens seccionaux, e em Itália com os beni ou demani civici, para falar em alguns casos da chamada dominialidade cívica. ${ }^{21}$

A dominialidade proprietária individualista - como se pode observar em muitos casos invadiu esses espaços, como ainda o faz em terras indígenas, nas reservas naturais e outras do jaez no Brasil; porém, nos dias atuais o absolutismo jurídico vem sendo questionado e relativizado por diversos modelos novos de autorregulação, os quais refletem o caráter pluralístico das atuais sociedades nos textos constitucionais (como em Portugal 1976 e Espanha 1978) e no plano infraconstitucional, como é o caso da lei francesa de 1985, só para dar alguns exemplos estrangeiros. ${ }^{22}$ É o reflexo de uma nova realidade, que o constitucionalismo não criou, mas passa a respaldar.

No Brasil, o Código de 1916 trazia, no capítulo do condomínio, uma seção dedicada ao compáscuo (art. 646), ${ }^{23}$ mas que não foi mantida pelo

21 NABAIS, José Casalta. Alguns perfis da propriedade coletiva nos países do Civil Law. Coimbra: Coimbra, [1998], p. 224.

22 NABAIS, José Casalta. Alguns perfis da propriedade coletiva nos países do Civil Law. Coimbra: Coimbra, [1998], p. 226.

23 Dispunha o art. 646 do CC/16: Se o compáscuo em prédios particulares for estabelecido por servidão, reger-se-á pelas normas desta. Se não, observar-se-á, no que lhe for 
Código atual de 2002. Em contrapartida, a CRFB de 1988 e a legislação infraconstitucional trazem novas espécies de propriedade como a quilombola e as Reservas Extrativistas, assim como dão foro participativo à definição pluralista dos conteúdos da propriedade urbana, mediante o Estatuto da Cidade e o Plano Diretor. É esse fenômeno, das propriedades especiais, que agora merece enfoque; não sem antes repetir que elas surgem no bojo de um constitucionalismo que transforma os direitos patrimoniais.

\section{As propriedades especiais}

Não há tradição em dominialidade cívica no Brasil, porém, o fenômeno das novas propriedades especiais, em sua diversidade e pluralidade de formas, é uma realidade dos tempos atuais, que a doutrina, de um modo geral, não tem destacado. Elas rompem com a autorreferencialidade da propriedade moderna codificada e seu sistema político institucional, relativizando os seus elementos, o que não significa a sua eliminação, como destaca Rodotá: ${ }^{24}$ a propriedade, com sua lógica sempre será o único, verdadeiro princípio e valor constitutivo de todo o sistema. Não só na modernidade, mas também na pós-modernidade. Os valores proprietários permanecem.

A propriedade especial relativiza o indivíduo como interlocutor, mediante titularidades coletivas, como ocorre, por exemplo, na propriedade quilombola. Relativiza também o objeto da propriedade, que antes se restringia aos bens corpóreos, e agora pode abranger verdadeiras entidades ou complexos de situações jurídicas partilhadas coletivamente, inclusive com órgãos públicos ou interesses privados concorrentes, como se observa na reserva extrativista. É a relativização do próprio conteúdo do Direito: numa o uso, gozo e disposição à mercê do voluntarismo individualista, e na outra a dependência de procedimentos e de decisões compartilhadas.

aplicável, o disposto neste capítulo, caso outra coisa não estipule o título de onde resulte a comunhão de pastos. Parágrafo único. O compáscuo em terrenos baldios e públicos regular-se-ão pelo disposto na legislação municipal.

24 RODOTÁ, Stefano. Il terribile diritto: studi sulla proprietà privada. Bolonha: Il Mulino, 1990, p. 21. No original, relativização perché la proprietà, com la sua lógica, sarebbe l'unico, vero principio e valore costitutivo dell'intero sistema. 
Em outras palavras e de outro ângulo, é a substituição do monismo jurídico pelo pluralismo de fontes, sob a égide dos instrumentos constitucionais e das leis de natureza participativa e de contratos coletivos. $O$ perfil legal da propriedade especial inclui: origem constitucional, lei(s) especial(is), ente estatal de apoio e mediação (INCRA, FUNAI, ou Agência reguladora). Importa autonomia e novas classificações jurídicas de bens, incluindo, além do público e do privado, o bem coletivo (ambiente, cultura), sob nova taxonomia. E às vezes se dirá entidade no lugar de bem; investidura ao invés de modo de aquisição e titularidade em vez de domínio.

Essas modificações de reconstituição de todo o paradigma da propriedade (em sentido amplo), afetam outros institutos jurídicos de direito privado como o direito de vizinhança; as interferências não se darão, apenas, entre imóveis, mas entre propriedades em sentido amplo, impondo harmonização e compatibilidade com interesses de dimensões não imaginadas pela propriedade moderna, como o equilíbrio ecológico, por exemplo. Como diz Rodotá: ${ }^{25}$ compatibilidade entre decisões individuais e outros interesses [omissis] como parte de um patrimônio comum (da coletividade, de um povo, da humanidade inteira) ou como direitos das gerações futuras.

\section{Propriedades especiais: classificação}

Esse rompimento do paradigma de la proprieté, abre horizonte à pluralidade de formas proprietárias, e será tarefa da doutrina criar as classificações dessas novas propriedades que se debuxam no horizonte da pós-modernidade. Podem ser identificadas entre outras: as propriedades especiais particulares, as público-privadas e as propriedades especiais coletivas, sendo que essas últimas podem ser patrimoniais ou étnicas e extrapatrimoniais. A propriedade especial particular é a que tem dimensão

25 RODOTÁ, Stefano. Il terribile diritto: studi sulla proprietà privada. Bolonha: Il Mulino, 1990, p. 21. No original: Compatibilità tra decisioni individuali ed altri interessi [omissis] come parte di um patrimonio comune (di collettività, di um popolo, dell'intera umanità) o come diritti delle generazioni future. 
própria $^{26}$ de função social, como a urbana e a rural, ou regime jurídico diferenciado, como a intelectual, e a público-privada, que é empresária.

\subsection{Propriedades especiais particulares}

A propriedade urbana é a destinada à moradia, ao comércio e à indústria, regra geral situada na zona urbana, ou mesmo na zona rural. ${ }^{27}$ É propriedade comum quanto ao objeto (bens corpóreos imóveis); quanto ao regime jurídico (de direito real, a título singular ou sob condomínio); quanto à aquisição (os modos previstos no Código Civil) e quanto às limitações (perante regulamentos administrativos, direito de vizinhança e outros). Porém, tem um grande diferencial que é a função social. Função social que é cumprida quando atende às exigências fundamentais de ordenação da cidade expressas no plano diretor (CRFB, art. 182, § $2^{\circ}$ ).

As diretrizes gerais desse novo perfil da propriedade urbana estão previstas no Estatuto da Cidade, Lei n. 10.257/2001, além das leis de parcelamento do solo urbano (n. 6.766/1979) e das incorporações (n. 4.591/1964), e numa lei municipal participativa que é o plano diretor, na alçada do povo constitucional. A discussão, a aprovação, as modificações, as emendas devem ser debatidas com a comunidade municipal mediante os instrumentos previstos, como audiências públicas, plebiscitos e referendos; a Câmara de Vereadores, no final, aprova o que foi decidido na discussão coletiva, à semelhança da auctoritas patrum do Senado Romano.

${ }^{26} \mathrm{O}$ que não quer dizer não estejam as demais propriedades sob a égide do princípio da função social; a alusão é ao registro expresso da CRFB nos art. 182, §2 e 186.

27 Há dois critérios para distinguir urbano de rural. BORGES, Roxana Cardoso Brasileiro. Função ambiental da propriedade rural. São Paulo: LTr, 1999, p. 59-64. FERREIRA, Pinto. Curso de direito agrário. São Paulo: Saraiva, 1994, p. 171-173. O primeiro é o finalístico ou da destinação, do art. $4^{\circ}$ da Lei n. 8.629/93 e segundo o topográfico ou geográfico do Código Tributário Nacional, Lei n. 5.172/66, art. 29 e 32, $\S \S 1^{\circ}$ e $2^{\circ}$. Ao contrário da autora (Borges) e da voz corrente da doutrina, entende-se que um não exclui o outro, aplicando-se o que for adequado ao caso concreto. Por exemplo, uma área rural favelada pode ser objeto de usucapião coletiva, já que pela destinação passou, com o tempo e a posse, a urbana. Quem adota o critério geográfico seria obrigado a negar a usucapião, o que não parece correto nem justo. 
Por isso é propriedade especial. ${ }^{28}$ Seu conteúdo já não é definido exclusivamente pelo regime jurídico do direito comum codificado, como reza o paradigma da propriedade moderna; é a comunidade municipal, mediante lei e instrumentos participativos e democráticos, ou seja, pelo pluralismo jurídico, quem define o conteúdo específico de uso e gozo do solo na dimensão social e também particular, por consequência. Pluralismo que expressa conciliação de todos os interesses comunitários: particulares, públicos, ambientais, coletivos - e que positivados no plano diretor vão definir o exato conteúdo de direito de cada unidade e o modelo de cidade.

A propriedade especial rural assemelha-se à categoria antitética da propriedade urbana no que tange à dimensão de direito comum; mas tem figurino distinto quanto ao regime jurídico e à função social. ${ }^{29}$ Pelo art. $4^{\circ} \mathrm{da}$ Lei n. 8.629/93, rural é o prédio rústico de área contínua, qualquer que seja a sua localização, que se destine ou possa se destinar à exploração agrícola, pecuária, extrativo-vegetal, florestal ou agroindustrial. ${ }^{30}$ Pelo critério topográfico ${ }^{31}$ ou geográfico do Código Tributário Nacional, Lei n. 5.172/66, art. 29 e $32 \S \S 1^{\circ}$ e $2^{\circ}$, é o imóvel que se situa fora do perímetro urbano, tem cadastro rural $^{32}$ e recolhe imposto territorial rural. (Lei n. 9.393/96).

Esse imóvel cumpre a função social (art. 186 da CRFB), quando tem aproveitamento racional e adequado, respeita o meio ambiente e as

\footnotetext{
28 A sua unidade é o lote urbano, que não representa um terreno isolado, porém uma série de equipamentos e serviços públicos agregados (Lei n. 6.766/79, art. $2^{\circ}$, $\S 4^{\circ}$ e $\S 5^{\circ}$ ), de acordo com as diretrizes de função social da cidade (Estatuto da Cidade, art. $2^{\circ}$ ).

29 FERREIRA, Pinto. Curso de direito agrário. São Paulo: Saraiva, 1994, p. 3. A propriedade imóvel rural toma novo rumo e passa a constituir novo ramo do direito, o direito agrário, desde as diretivas do I Congresso Agrário de 1921, realizado na Itália.

30 A Lei n. 8.171/91, que dispõe sobre política agrícola, em seu artigo $1^{\circ}$, juntamente com os fundamentos, objetivos, competências institucionais, ações e instrumentos da referida política, inclui a atividade pesqueira como atividade agrícola.

$31 \mathrm{O}$ art. 49 da Lei n. 9.985/2000, a propósito, dispõe: A área de uma unidade de conservação do Grupo de Proteção Integral é considerada zona rural, para os efeitos legais. Parágrafo único. A zona de amortecimento das unidades de conservação de que trata este artigo, uma vez definida formalmente, não pode ser transformada em zona urbana.

32 Leis n. 4.947/66 e 10.267/01.
} 
disposições que regulam as relações de trabalho e favorecem o bem-estar de proprietários e trabalhadores. As diretrizes constam do Estatuto da Terra (n. 4.504/1964) e da Lei n. 8.629/93. Sua tributação é orientada aos fins constitucionais (Lei n. 9.393/96 sobre Imposto Territorial Rural - ITR), e à política agrícola (Leis n. 8.171/91 e 8.174/91) preconizando: propriedade familiar, crédito, renovação tecnológica, assistência técnica e extensão rural, seguro agrícola, cooperativismo, irrigação, eletrificação rural.

Como o plano diretor abrange todo o território do município, a propriedade rural também apresenta uma dimensão participativa. Assim, a solução local das questões agrárias pode e deve ser discutida nesse fórum coletivo, que define a função social e os níveis de utilização e otimização do território municipal. A União Federal e o Parlamento estabelecem as diretrizes da propriedade rural e da reforma agrária e os órgãos específicos (como o INCRA) cuidam de seu cumprimento; mas é na ágora local ${ }^{33}$ que se definem, pelos instrumentos constitucionais, do plano diretor e de leis especiais, ${ }^{34}$ a extensão e o conteúdo de função social dos imóveis rurais.

Com esse viés, a questão agrária pós-moderna muda de rumo, atrela-se a uma nova ideia de desenvolvimento e defronta-se com novos horizontes de propriedades especiais. A Lei n. 9.985/2000, por exemplo, consagra uma variante de propriedade rural, que é a Reserva Particular do Patrimônio Natural - RPPN. ${ }^{35}$ Por iniciativa do proprietário, o imóvel é total ou parcialmente incluído no Sistema Nacional de Unidades de Conservação - SNUC, com o objetivo de conservar a diversidade biológica. Isso se dá mediante Termo de Compromisso firmado perante as autoridades ambientais (se houver interesse público), averbado no Registro de Imóveis.

\footnotetext{
33 Nessa arena coletiva estarão com a comunidade não só as autoridades locais, mas as autoridades estaduais e federais, especialmente do INCRA. Participação é processo inclusivo, deliberativo e de consenso de todas as esferas da sociedade e do Estado.

${ }^{34} \mathrm{O}$ art. 99 da Lei n. 8.171/91, por exemplo, obriga o proprietário rural a recompor a Floresta Legal do Código Florestal (Lei n. 4.771/65, com a redação da Lei n. 7.803/89) em pelo menos 30 avos da área total por ano.

35 É o art. 21 da Lei n. 9.985/2000 (regulamenta o art. 225, § 1º, incisos I, II, III e VII da Constituição Federal, institui o Sistema Nacional de Unidades de Conservação da Natureza e dá outras providências), regulamentado pelo Decreto n. 5.746/2006.
} 
É um modelo especial de propriedade, em que o proprietário, espontaneamente, abre mão das prerrogativas de direito subjetivo comum particular para conferir ao imóvel uma finalidade de interesse social ou coletivo. As RPPNs podem ter espectros variados, sendo que algumas não têm objetivos econômicos e outras podem voltar-se à visitação, com objetivos turísticos, recreativos e educacionais ou à pesquisa científica (art. $21, \S 2^{\circ}$ ). A exploração dos recursos naturais não se exclui desse modelo, mas depende de um Plano de Manejo $^{36}$ (ou de proteção e de gestão da Unidade) elaborado com as autoridades ambientais e outras parcerias.

Essas duas categorias de propriedade especial privada - rural e urbana - redefinidas pela ordem constitucional de 1988 demonstram que o individualismo jurídico e o voluntarismo estatal que presidiram as codificações deram lugar à funcionalização do direito de propriedade, perante os desafios da sustentabilidade e da solidariedade social. À dicotomia público/privado acrescenta-se hoje um terceiro elemento, que é a dimensão do coletivo, estampada nos direitos sociais fundamentais. A própria reforma agrária deve ser implantada sob a égide das propriedades especiais e executada sob nova orientação de exercício e tutela.

A propriedade intelectual ${ }^{37}$ é garantida pelo art. $5^{\circ}$, XXVII a XXIX da CRFB, tendo em vista o interesse social e o desenvolvimento tecnológico e econômico do País, e pauta-se por duas leis básicas, n. 9.610/1998 (direito autoral) e n. 9.279/96 (propriedade industrial). ${ }^{38}$ Aparta-se do direito comum pelo objeto, que é imaterial, reunindo no gênero categorias como direitos autorais, marcas, indicações geográficas, desenhos industriais, patentes, topografia de circuitos integrados, proteção de informação confidencial,

\footnotetext{
${ }^{36}$ FERREIRA, Lourdes M. et al. Roteiro metodológico para elaboração de Plano de Manejo para Reservas Particulares do Patrimônio Natural. Brasília: IBAMA, 2004. Disponível em: <www.ibama.gov.br>. Acesso em: 25 fev. 2008.

37 RUGGIERO, Roberto de. Instituições de direito civil. Tradução de Paolo Capitanio. Campinas: Bookseller, 1999, v. 2, p. 462. Todo o produto do engenho humano pertence ao seu autor, mas tal pertença só por analogia se pode chamar propriedade e não identificarse com ela. Melhor é, pois, falar de direitos sobre bens imateriais [omissis].

38 Existem outras leis no setor, como a n. 969/98 (programas de computador), 9.456/97 (cultivares), 9.615/98 (desporto), 8.974/95 (engenharia genética).
} 
controle de práticas de concorrência desleal, tudo sob influência do direito internacional, ${ }^{39}$ e sob a égide da função social.

No plano do objeto, ela opõe direitos da personalidade e direitos morais a direitos patrimoniais, e na dimensão de função social coloca em confronto o interesse do titular com os interesses gerais da cultura e da ciência e de comunidades étnicas - como no caso de conhecimentos tradicionais associados ${ }^{40}$ (MP n. 2.186/2001). Seu regime jurídico é de legislação especializada, tutela específica pelo direito interno e por entidades supraestatais ${ }^{41}$ e princípios próprios. Esses princípios emanam da órbita internacional ${ }^{42} \mathrm{e}$ da órbita nacional, ${ }^{43}$ como especialidade da matéria, proteção da forma estética original, exclusividade da exploração.

A propriedade intelectual, portanto, é uma propriedade especial, cuja dimensão de função social deve ser examinada em contexto próprio, matéria que não se esgota aqui. É um dos casos que ilustram muito bem o conceito de propriedade em sentido amplo; não se pauta pelo

39 O Decreto 1.355/1994 promulga a Ata Final que incorpora os Resultados da Rodada Uruguai de Negociações Comerciais Multilaterais do GATT (OMC), Trade Related Aspects of Intelectual Property Rights - TRIPS, em português Acordo sobre os Aspectos dos Direitos de Propriedade Intelectual Relacionados com o Comércio - ADPIC, cujo objeto de proteção engloba essas categorias de direitos.

40 A MP foi editada sob n. 2.052/2000, sofrendo alterações, até a MP 2.186-16, regulamentada pelo Dec. 3.945/2001, modificado pelo Dec. 4.946/2003. Essa legislação confere direito subjetivo em favor de uma comunidade, sobre informações ou práticas locais, individuais ou coletivas, com valor real ou potencial, associadas ao patrimônio genético. Patrimônio genético são informações de origem genética de espécime vegetal, fúngico, microbiano ou animal, obtidos de organismos vivos ou mortos.

41 A Organização Mundial do Comércio preocupa-se com os aspectos comerciais internacionais da propriedade intelectual, enquanto a Organização Mundial da Propriedade Intelectual - OMPI www.wipo.int, International Conference on Intelectual Property WIPO, ocupa-se da harmonização e guarda e administração dos tratados dos tratados. A União Internacional para Proteção das Obtenções de Variedades Vegetais - UPOV www. upov.org.es dedica-se à proteção internacional de cultivares.

42 Princípios internacionais seriam: tratamento nacional e da nação mais favorecida, proteção automática e proteção independente.

43 Princípios da órbita nacional seriam: especialidade da matéria, proteção da forma estética original, exclusividade da exploração, limitabilidade no tempo, restritividade da interpretação, facultatividade do registro e irrenunciabilidade do direito moral. 
paradigma estreito da modernidade, mas pelo arcabouço constitucional da República participativa. Nesse diapasão, enlaça-se com a territorialidade, a condominialidade, os conhecimentos coletivos associados, e constitui as propriedades étnicas; sem falar que na sua conformação mais tradicional, sofre ampla transformação em face do coletivo e da função social.

\subsection{Propriedade especial público-privada}

A propriedade especial público-privada é fenômeno mais recente. A Propriedade Comum do Código Civil - que assegura como paradigma a plenitude de direito subjetivo particular sobre os bens da natureza - tem no reverso a réplica antitética da propriedade pública, regida pelo Direito administrativo: nela o Estado exerce sobre os bens públicos uma função, vinculada à lei. Com o poder de polícia, protege os bens de uso comum do povo, serve-se dos bens de uso especial ou do patrimônio administrativo como instrumento de seus serviços e dispõe dos bens dominicais nas suas necessidades. ${ }^{44}$ A propriedade Especial Público-Privada tem outro escopo.

Ela surge com o desenvolvimento econômico, ${ }^{45}$ tendo por objeto bens nacionais, que são explorados por empresas estatais ou privadas, sob

${ }^{44}$ MEIRELLES, Hely Lopes. Direito administrativo brasileiro. 24. ed. São Paulo: RT, 1999, p.461. Opta-se por este autor, em nome de todos os outros, em face de sua popularidade até o passado mais recente. Em verdade, essa classificação reflete a do art. 66 do Código Civil de 1916. Mello adota o mesmo critério e assim define bem público: Bens públicos são todos os bens que pertencem às pessoas jurídicas de Direito Público, isto é, União, Estados, Distrito Federal, Municípios, respectivas autarquias e fundações de Direito Público (estas últimas, aliás, não passam de autarquias designadas pela base estrutural que possuem), bem como os que, embora não pertencentes a tais pessoas, estejam afetados à prestação de um serviço público. O conjunto de bens públicos forma o domínio público, que inclui tanto os bens imóveis como móveis. MELLO, Celso Antônio Bandeira de. Curso de direito administrativo. 12. ed. São Paulo: Malheiros, 2000, p. 727.

45 No início da República, o regime jurídico era o do art. 526 do CC/16, ou seja, as riquezas pertenciam ao dono do solo. A Constituição Federal de 1934 (art. 118 e 119) passou a considerar determinadas riquezas - jazidas, quedas d'água - como propriedade distinta do solo para o efeito de exploração ou aproveitamento industrial, na dependência de autorização ou concessão federal, na forma da lei. A reforma começara pela EC de 03 de setembro de 1926, que suprimiu do art. 34 o n. 26, da Constituição de 1891: Art. 34 - Compete privativamente ao Congresso Nacional: 29 -Legislar sobre terras e minas 
concessão ou autorização da União Federal, a teor dos art. 20, V, VIII, IX, 176 e parágrafos e 177, incisos e parágrafos da CRFB. É o caso de jazidas de petróleo, ${ }^{46}$ gás natural, hidrocarbonetos fluidos e demais recursos minerais e potenciais de energia hidráulica, como propriedade distinta do solo: mediante autorização ou concessão da União, no interesse nacional, por brasileiros ou empresa constituída sob as leis brasileiras e que tenha sede e administração no País, na forma da lei (CRFB, art. 176, § $1^{\circ}$ ).

O plano infraconstitucional, a exploração desse potencial de propriedade se dá na forma de legislação específica de cada setor, mediante regime empresarial, como por exemplo: DL 227/67 (Código de Minas); Lei n. 7.781/89 (minerais nucleares e derivados); Lei n. 9.478/97 (política energética nacional e atividades relativas ao monopólio do petróleo); ${ }^{47}$ Lei n. 8.901/94 (extração seletiva de madeira em florestas públicas), ${ }^{48}$ (lei 11.284/2006 (participação do proprietário do solo nos resultadas da lavra). Já as águas subterrâneas pertencem ao Estado Federado, na forma do art. 21, XIX da CRFB e da Lei n. 9.433/97 (institui a política nacional de recursos hídricos).

O Código Civil/02 passou a contemplar expressamente a propriedade das riquezas nacionais do subsolo por intermediação da União, conforme reza o art. 1.473, V, combinado com o art. 1.230; permitindo, inclusive, que ela sirva de objeto de hipoteca, independentemente do solo. É evidente que isso não a retira da esfera e dos desígnios constitucionais da ordem econômica e social, especialmente da dimensão coletiva e dos deveres perante o ambiente. Trata-se de uma propriedade especial, cuja dimensão público/privada e de função social, confere-lhe uma condição de exercício que não pode ser confundida com a da empresa privada comum.

de propriedade da União. Permaneceu, assim, apenas o art. 64 da CF/1891, que dispunha, até 1934, o seguinte: Pertencem aos Estados as minas e terras devolutas situadas em seus respectivos territórios.

46 Petróleo, segundo o art. 6º, I, da Lei n. 9.478/97, é: todo e qualquer hidrocarboneto líquido em seu estado natural, a exemplo do óleo cru e condensado.

47 Em agosto de 2009 seria apresentado o marco regulatório da exploração do petróleo do pré-sal, criando o Sistema de Partilha dos contratos de exploração, sem prejuízo do sistema dos contratos de Concessão tradicional.

48 As florestas públicas também podem ser exploradas de forma sustentável em outros regimes que não esse de empresa privada. São as modalidades da Lei n. 9.985/2000. 
O caráter especial dessa propriedade decorre do objeto, da investidura pública e do regime de utilização por leis próprias, mediante empresas privadas ou públicas, ${ }^{49}$ sendo que estas últimas têm previsão expressa de função social no art. $173, \S 1^{\circ}$ e inciso I da CRFB, devendo funcionar $s o b$ fiscalização do Estado e da Sociedade. Nesse campo atuam as chamadas Agências Reguladoras, tais como a Agência Nacional da Energia ElétricaANEEL, Agência Nacional de Petróleo-ANP, Agência Nacional de Telecomunicações-ANATEL, que correspondem mutatis mutandis à FUNAI na propriedade indígena e ao INCRA na propriedade agrária.

\subsection{Propriedades especiais coletivas: patrimoniais (étnicas) e extrapa- trimoniais (coletivas propriamente ditas)}

A segunda categoria de propriedade especial é a coletiva, que no plano patrimonial é a propriedade étnica. Destacam-se aqui três espécies: propriedade indígena, propriedade quilombola e propriedade de reservas extrativistas por populações tradicionais (Lei n. 9.985/2000). A CRFB estabelece as linhas fundamentais do direito étnico, nos artigos 215 e 216, e bem assim, cria modelos especiais de propriedade, que fogem tanto do padrão do Código Civil quanto do figurino administrativo da propriedade pública. Não se trata de apropriação de terra por indivíduo ou pluralidade de sujeitos privados, como na usucapião urbana coletiva, por exemplo.

Trata-se de propriedade diferenciada, especial, que importa reconhecimento e legitimação de uma territorialidade, histórica e antropologicamente construída, e preservada em torno de uma identidade cultural, em torno de saberes e costumes de um grupo étnico ou local; seja de índios seja de quilombolas, seja, por extensão, de comunidade de pescadores ou ribeirinhos, seringueiros, coletores de frutos. É propriedade que possui regime jurídico especial, em que não se fala em usucapião ou alienação nos moldes do direito comum, mas de outros modos de aquisição e outras formas de exercício e tutela do direito, cada uma na sua especificidade.

49 Nesse âmbito, a Lei Geral das Agências Reguladoras n. 9.986/2000; a Lei n. 8.987/1995, que dispõe sobre o regime de concessão de permissão de serviços públicos previstos no art. 175 da Constituição Federal, e dá outras providências; e a Lei n. 9.074/1995, que estabelece normas para outorga e prorrogações das concessões e permissões de serviços públicos, e dá outras providências. www.planalto.gov.br. 
A propriedade étnica caracteriza-se como reparatória afirmativa, em favor de negros e índios, principalmente - tão prejudicados pelo processo civilizatório nacional - os quais passam a ter assegurado o direito de reprodução sócio-cultural das tradições ancestrais; sem necessidade de se submeter ao modelo hegemônico da propriedade comum. Valorizando a diversidade étnica e a dimensão multicultural, a Lei Maior, com a propriedade étnica, enriquece a humanidade, pois garante modelos de vida comprometidos com a preservação da natureza, com a sustentabilidade e o resgate de valores milenares, que nos legaram a hegemonia do planeta.

Na propriedade étnica de quilombos, por exemplo, é o grupo que se define como sujeito e é o próprio grupo que estabelece os conteúdos ou o perfil de exercício da mesma. Direito subjetivo, é coletivo pro indiviso e alia à territorialidade os conhecimentos tradicionais, de forma que o grupo étnico pode reproduzir-se segundo os seus usos, os seus costumes e a sua tradição, a despeito da lógica civilizitória que o cerca. Há, portanto, diz Rocha, ${ }^{50}$ de prevalecer, para fins de pertencimento, a consciência da identidade, nos termos da Convenção 169 da OIT sobre Povos Indígenas e Tribais, ratificada pelo Brasil. Isso dito, passa-se a examinar cada uma delas.

A Propriedade especial coletiva indígena está prevista no art. 231 da CRFB e é regulada pela Lei n. 6.001/73 (Estatuto do Índio). Na dimensão de direito étnico possui várias Convenções internacionais ratificadas pelo Brasil, ${ }^{51}$ que lhe conformam o regime jurídico. Na esfera governamental

50 ROCHA, Maria E. Guimarães. O Decreto n. 4.887/2003 e a regulamentação das terras dos remanescentes das comunidades de quilombos. Disponível em www.presidencia.gov. br acesso em 22 jun. 2007. O art. 1', al. "b", 2 dispõe: A consciência de sua identidade indigena ou tribal deverá ser considerada como critério fundamental para determinar os grupos aos que se aplicam as disposições da presente convenção. O Dec. é n. 58.824/66, aprovado pelo Decreto Legislativo n. 20/65, que trata, nos art. 11-14, das terras indígenas (Convenção sobre Populações Indígenas e Tribais).

${ }^{51}$ Dec. n. 58.824/68 Convenção 107 da OIT tratando da propriedade indígena; Convenção 169 da OIT sobre povos indígenas e tribais em países independentes - ratificada em 2002, Dec. Leg. 143/2002 (disponível em: <www.socioambiental.org>. Acesso em: 23 fev. 2008 e WOLKMER, Antônio Carlos (Org). Pluralidade jurídica na América Luso-Hispânica. Porto Alegre: Livraria do Advogado, 1998; e a Convenção da UNESCO sobre a diversidade das expressões culturais, Decreto Legislativo n. 485/2006 (disponível em: <www.unesco. org.br>. Acesso em: 23 fev. 2008. 
atua a Fundação Nacional do Índio (Lei n. 5.371/67), ${ }^{52}$ que estabelece e executa a política indigenista brasileira, com poderes, inclusive, de representação e assistência jurídica inerentes ao regime tutelar do índio. $\mathrm{O}$ art. 232 da CRFB legitima os próprios índios e suas comunidades defender seus direitos e interesses em juízo, ${ }^{53}$ intervindo o Ministério Público.

O Código Florestal, Lei n. 4.771 de 1965, art. $2^{\circ}, \S 2^{\circ}$ dispõe que as florestas que integram o patrimônio indígena ficam sujeitas ao regime de preservação permanente pelo só efeito da referida lei. ${ }^{54}$ Já o art. 231 da CRFB reconhece aos índios, ${ }^{55}$ além da sua organização social, costumes, línguas, crenças e tradições, os direitos originários sobre as terras que tradicionalmente ocupam, e bem assim as que habitam em caráter permanente, as que utilizam para suas atividades produtivas, as que são imprescindiveis à preservação dos recursos ambientais necessários a seu bem-estar e as que forem necessárias a sua reprodução física e cultural.

É o instituto do indigenato, que permite aos índios viver em suas terras segundo seus usos, costumes e tradições - devendo, a União, demarcá-las, protegendo e fazendo respeitar todos os seus bens. O regime jurídico da propriedade indígena não é de domínio propriamente dito, mas de posse permanente, com usufruto exclusivo das riquezas do solo, dos rios e dos lagos; de sorte que, se for necessária a sua remoção (após deliberação do Congresso Nacional), no caso de catástrofe, de epidemia que ponha em risco a sua população ou de interesse da soberania do país, o retorno será imediato, tão logo tenha cessado o risco ou a causa do afastamento.

${ }^{52} \mathrm{O}$ art. $1^{\circ}$ da Lei n. 5.371/67 numera as finalidades e princípios da FUNAI, sendo de se destacar o respeito a sua (dos índios) cultura, usufruto exclusivo dos recursos naturais de suas terras e o despertar do interesse coletivo para a causa indigenista.

53 Intervindo sempre o Ministério Público.

54 A Lei n. 4.771/65 é regulamentada, nos art. 44-46, pelo Dec. n. 88.895/83.

$55 \mathrm{O}$ art. $3^{\circ}$ do Estatuto do Índio, Lei n. 6.001/73, define índio como todo indivíduo de origem e ascendência pré-colombiana que se identifica e é identificado como pertencente a um grupo étnico cujas características culturais o distinguem da sociedade nacional; comunidade indígena ou grupo tribal é o conjunto de família ou comunidades índias, quer vivendo em estado de completo isolamento, quer em contatos intermitentes ou permanentes com outros setores da comunhão nacional, sem, contudo, estarem neles integrados. O parágrafo único do art. $4^{\circ}$ do Código Civil estabelece que a capacidade dos indios será regulada por legislação especial. 
Em compensação, à diferença do art. 176 da CRFB, as riquezas do subsolo e os potenciais de energia hidráulica, nas terras indígenas, não pertencem à União, e só podem ser exploradas com autorização do Congresso Nacional, ouvidas as comunidades afetadas, que têm assegurada participação nos resultados da lavra (art. 231, § $3^{\circ}$ ). Não tem sido tranquila a questão da demarcação das terras indígenas (Dec. n. 1.775/1996), em face de conflitos e pretensões de não índios, como se observa, especialmente, no caso da Reserva Raposa Serra do Sol, que começou em 1919, foi realizada em 1993, homologada em 2007 e suspensa em 2008 até 2009 pelo STF. ${ }^{56}$

A Propriedade quilombola, instituída no ADCT da CRFB/88, art. 68 c/c art. 215 e 216 da CF e Dec. n. 4.887/2003, é reconhecida aos remanescentes das comunidades de quilombos que estejam ocupando tais terras. Conforme o Dec. n. 4.887/2003, art. $2^{\circ}$, consideram-se remanescentes das comunidades dos quilombos os grupos étnicoraciais, segundo critérios de autoatribuição, com trajetória histórica própria, dotados de relações territoriais específicas, com presunção de ancestralidade negra relacionada com a resistência à opressão histórica sofrida. É propriedade coletiva, que inclui direitos culturais, cujas manifestações devem ser protegidas pelo Estado.

Os quilombos incluem-se na categoria de comunidade local. É grupo humano distinto por suas condições culturais, que se organiza, tradicionalmente, por gerações sucessivas e costumes próprios, e que conserva suas instituições sociais e econômicas. A essas comunidades de afrodescendentes, estabelece o art. 68 do ADCT, é reconhecida a propriedade definitiva das terras que estejam ocupando, devendo o Estado emitir-lhes os títulos respectivos. Em complemento, o $\S 5^{\circ}$ do art. 216 da CRFB, na defesa da cultura nacional, decreta o tombamento de todos os sítios detentores de reminiscências históricas dos antigos quilombos.

\footnotetext{
56 A Reserva Raposa Serra do Sol possui área contínua de 1,7 milhão de ha. Com $1.000 \mathrm{~km}$ de perímetro, localizada em Roraima, na fronteira do Brasil com Venezuela e Guiana. É ocupada por índios Pemons e Capons, povos de filiação Caribes. A demarcação foi contestada por não índios e o Governo de Roraima. Em 2007, o STF determinou a desocupação da Reserva, mas em 2008 suspendeu a operação de desintrusão, até o julgamento definitivo de março de 2009 a favor da comunidade indígena, por 10 votos a 1, ordenando a saída dos não índios da Reserva.
} 
A propriedade quilombola apresenta algumas diferenças em relação à propriedade indígena: trata-se de propriedade dominial titulada (e não usufruto), mas não inclui como aquela, as riquezas distintas do solo enumeradas no art. 176 da CRFB. O critério de identificação das áreas é o da autodefinição da própria comunidade. Já o seu reconhecimento, delimitação, demarcação e titulação competem ao Ministério do Desenvolvimento Agrário, por meio do Instituto Nacional de Colonização e Reforma Agrária - INCRA, sem prejuízo da competência concorrente dos Estados, do Distrito Federal e dos Municípios (art. $3^{\circ}$ do Dec. n. 4.887/2003).

É propriedade que assegura a participação dos interessados, diretamente ou por representantes, em todas as fases do procedimento respectivo (art. $6^{\circ}$ do Dec. n. 4.887/2003), o que se estende ao exercício - como propriedade procedimental - e à tutela (tanto no plano intrínseco, nos conflitos internos, como no plano extrínseco, nos conflitos com terceiros). A titulação é mediante outorga de título coletivo e pró-indiviso, com cláusula de inalienabilidade, imprescritibilidade e impenhorabilidade, já que outra é a sua racionalidade. O título é levado ao Registro de Imóveis, constando em nome de associação legalmente constituída pela comunidade beneficiada.

Se envolver terrenos de marinha, marginais de rios, ilhas e lagos, o INCRA e a Secretaria do Patrimônio da União tomarão as medidas cabíveis para a expedição do título. No caso de sobreposição a unidades de conservação, áreas de segurança nacional, faixa de fronteira e terras indígenas, o INCRA, o IBAMA, a Secretaria-Executiva do Conselho de Defesa Nacional, a FUNAI e a Fundação Cultural Palmares tomarão as medidas necessárias, conciliando o interesse do Estado. Quando incidir sobre terras de propriedade dos Estados, do Distrito Federal ou dos Municípios, o INCRA deve encaminhar os autos para os entes responsáveis pela titulação.

Se houver oposição de título de domínio particular não invalidado por vício de nulidade, prescrição ou comisso, e nem tornado ineficaz por outros fundamentos, o caminho será a desapropriação, conduzida pelo INCRA (art. 13 do Dec. n. 4.887/2003). Vale dizer, os direitos dos quilombolas não serão prejudicados por isso, mesmo porque o INCRA estará autorizado a ingressar no imóvel, uma vez decretado o 
procedimento respectivo (art. 13, $\S 1^{\circ}$ do Dec. n. 4.887/2003). Prevalece juridicamente a condição de propriedade quilombola, restando aos demais pretendentes não mais que o direito de indenização, a cargo do poder público competente.

É propriedade especial, ademais, porque o seu conteúdo e o seu exercício serão definidos pela própria comunidade, de acordo com seus costumes e tradições, sendo inegável, neste aspecto e perante o direito comum, certa analogia com o direito internacional privado: salvo ordem pública e soberania nacional. A investidura consagra regime jurídico especial, de efeitos retroativos, que torna a área imune a qualquer perda a outro título de direito comum, como usucapião, por exemplo. Aplica-se por analogia o que dispõe o $\S 6^{\circ}$ do art. 231 da CRFB para a propriedade indígena, sem prejuízo de eventuais direitos de terceiros no caso de desapropriação. ${ }^{57}$

À semelhança da propriedade indígena, com a FUNAI, os quilombolas também contam com o apoio de uma instituição própria; é a Fundação Cultural Palmares, encarregada de manter cadastro geral das comunidades; de acompanhar processos de titulação, tombamento do seu patrimônio cultural, defesa dos seus interesses em geral, articulação com as autoridades governamentais, especialmente junto ao Comitê Gestor do Etno Desenvolvimento, coordenado pelo Secretário Especial de Políticas de Promoção da Igualdade Racial a que se refere o art. 19 do Dec. 4.887/2003. Porém, a Fundação é ente auxiliar, não exclui a autonomia do quilombo.

57 BRASIL. Artigos, pareceres, memoriais e petições: o Decreto n. 4.887/2003 e a regulamentação das terras dos remanescentes das comunidades dos quilombos. Disponível em: $<$ http://www.planalto.gov.br / ccivil_03 / revista / Rev_68/ Artigos / Art_Maria.htm>. Acesso em: 24 fev. 2008. Ressalva o direito de indenização do particular, em caso de desapropriação das terras para quilombos, citando em reforço a seguinte opinião de Dalmo Dallari: a Constituição não declara a nulidade dos títulos anteriores, como o faz no caso das terras indigenas. Diferentemente dos índios que detêm a posse permanente e o usufruto exclusivo das áreas por eles tradicionalmente ocupadas (o domínio destas terras continua a ser da União - artigo $231 \S 2^{\circ}$ da CF/88), aos remanescentes de quilombos é reconhecido o domínio das terras. De tal forma, colocam-se em confronto a propriedade do particular e a dos quilombolas revista constitucionalmente. 
Há outras categorias assemelhadas, como a das comunidades caiçaras - que vivem de pesca e roça nas regiões litorâneas entre a Baía da Guanabara e Santa Catarina; ${ }^{58}$ a das comunidades faxinalenses do Paraná - que vivem de agricultura e criação de animais em terras coletivas. ${ }^{59} \mathrm{Se}$ propriedades especiais dessa natureza não fossem reconhecidas e respeitadas como tais pela ordem jurídica, a tendência seria o desaparecimento, pois não têm condições de competir com a propriedade individual, com suas cercas e mono-culturas. O regime do condomínio voluntário do CCB é absolutamente intolerante com sua feição de condomínio de mão comum.

\section{A propriedade coletiva extrativista ou propriedade de unidades} de uso sustentável por populações tradicionais é a que se estabelece em favor de tais coletividades sobre áreas de domínio público, transformadas por iniciativa federal, estadual ou municipal em Unidades de Conservação do Grupo de Uso Sustentável. ${ }^{60}$ Elas integram o Sistema Nacional de Unidades de Conservação da Natureza - SNUC, de que trata a Lei n. 9.985/2000 (art. 225, § $1^{\circ}$, incisos I, II, III da CRFB). À semelhança da propriedade indígena, ${ }^{61}$ ela não garante o domínio sobre a área, e sim a posse e o uso dos recursos naturais de forma limitada e sustentável. ${ }^{62}$

58 FELTRIN, Diego. Comunidade caiçara. Disponível em: <http://equipedesocioogia. wordpress.com/category/uncategorized/>. Acesso em: 15 nov. 2009.

59 POVOS E COMUNIDADES tradicionais realizam o $2^{\circ}$ Encontro Estadual em Faxinal. http://equipedesocioogia.wordpress.com/, acesso em 15 nov. 2009. NEIVERTH, Nayme; SAHR, Cicilian Luiza Löwen. Ações governamentais na Comunidade Faxinalense Taquari dos Ribeiros (Rio Azul/PR). Disponível em: <http://www.uepg.br>. Acesso em: 15 nov. 2009: Em dezembro de 2004 os povos tradicionais ganharam representação na... Comissão de Desenvolvimento Sustentável dos Povos e Comunidades Tradicionais. Em 2007 instituiu-se a Politica Nacional de Desenvolvimento Sustentável mas as políticas e ações muitas vezes não priorizam o etnodesenvolvimento no território faxinalense.

60 A Lei n. 9.985/2000 classifica as Unidades de Conservação em dois grupos; unidades de proteção integral, ou de uso indireto - como se dizia anteriormente - que visam à preservação das áreas com a diversidade biológica (Estação Ecológica, Reserva Biológica, Parque Nacional, Monumento Natural, Refúgio de Vida Silvestre) e unidades de uso sustentável.

${ }^{61}$ O subsolo e o espaço aéreo, sempre que influírem na estabilidade do ecossistema, integram os limites da unidade (art. 24 da Lei n. 9.985/2000), mas, evidentemente, não pertencem aos residentes tradicionais.

62 A propriedade extrativista apresenta semelhança também com a Concessão de Uso Especial para Fins de Moradia, da MP 2220/2001 e art. 1225, XI do CCB: quem possui 
O regime é vertido para contrato, que obedece a normas regulamentares (art. 23), firmado com as autoridades competentes, parcerias envolvidas e entidades da sociedade civil. Há diversas modalidades de unidades de conservação, ${ }^{63}$ mas a mais importante é a reserva extrativista, definida como área utilizada por populações extrativistas tradicionais, cuja subsistência baseia-se no extrativismo e, complementarmente, na agricultura de subsistência e na criação de animais de pequeno porte. O objetivo é proteger os meios de vida e a cultura das populações, e assegurar o uso sustentável dos recursos naturais da unidade de conservação.

Portanto, é propriedade coletiva, de cunho étnico, incidente sobre patrimônio nacional, instituída por lei, de conteúdo fixado em contrato coletivo, com participação popular, ${ }^{64}$ e que visa a compatibilizar biodiversidade, sociodiversidade e desenvolvimento sustentável, no contexto regional. ${ }^{65} \mathrm{Em}$ termos de conteúdo e de função social, é um tipo de propriedade rural, mas que se distingue, absolutamente, da propriedade rural particular e seu amplo espectro de liberdade como direito subjetivo. Trata-se de propriedade coletiva procedimental patrimonial. Por outro lado, desta difere outra espécie de propriedade coletiva, a extrapatrimonial.

como seu, por cinco anos ininterruptos e sem oposição, imóvel público situado em área urbana, de até $250 \mathrm{~m} 2$, utilizando-o para sua moradia ou de sua família, tem direito de concessão de uso especial para fins de moradia sobre o referido bem, desde que não seja proprietário ou concessionário, a qualquer título, de outro imóvel urbano ou rural (art. $1^{\circ}$ da MP 2.220/2001).

63 São elas, de acordo com o art.: Área de Proteção Ambiental: em geral extensa, com certa ocupação, voltada à sustentabilidade dos recursos naturais. Área de Relevante Interesse Ecológico: pequena extensão, com pouca ou nenhuma ocupação humana. Floresta Nacional: de espécies predominantemente nativas, em que se permite extração seletiva e atividade de pesquisa científica. Reserva de Desenvolvimento Sustentável: área natural com população tradicional com existência baseada em sistemas sustentáveis ao longo de gerações, adaptadas às condições ecológicas locais e com papel fundamental na manutenção da diversidade biológica.

64 Art. 27, § 2º, art. 30 e 32 da Lei n. 9.985/2000.

65 A compatibilização desses fatores está prevista no art. 26 da Lei n. 9.985/2000. 


\section{Propriedade coletiva extrapatrimonial ou coletiva propriamente dita: base constitucional da função social}

Rodotá ${ }^{66}$ levanta a questão com que se pretende deixar à discussão. A propósito da luta pela conquista da cidadania social, pergunta: o acesso à cidadania social deve dar-se através da Propriedade ou através dos direitos? Em outros termos e com outras palavras: as dimensões de tal cidadania moderna dependem dos bens que cada um pode adquirir no mercado ou justamente do reconhecimento de uma série de situações jurídicas que livram o cidadão da lógica mercantil? Pode-se perguntar da mesma forma: o ambiente deve ser protegido por uma proclamação de direito ou, mais que isso, ser uma propriedade titulada em favor de todos?

A segunda alternativa - acrescenta $\operatorname{Rodotá}^{67}$ - redimensiona quantitativa e qualitativamente a propriedade, porque significa romper o nexo propriedade-personalidade. A questão redistributiva, nessa linha, deixa de ser a questão central, e a relação entre indivíduo e bens deixa de ser necessariamente mediada pela lógica proprietária. ${ }^{68}$ Ora, esse aspecto é nuclear à função social da propriedade: seria ela solidariedade social do proprietário privado ou, mais do que isso, o confronto da propriedade com direitos fundamentais elevados ao mesmo status de direito subjetivo, na pele de uma nova propriedade, a Propriedade Coletiva Extrapatrimonial?

Observe e atente o leitor para o seguinte. Se for dado ao ambiente equilibrado e ao patrimônio histórico preservado - e aos demais direitos

${ }^{66}$ RODOTÁ, Stefano. Il terribile diritto: studi sulla proprietà privada. Bolonha: Il Mulino, 1990, p. 22. No original: L'accesso allá cittadinanza sociale deve avvernire attraverso la proprietà o attraverso i diritti? In altri termini: lê dimensioni di tale moderna cittadinanza dipendono daí beni che ciascuno puó acquistare sul mercato oppure dal riconoscimento di uma serie di situazioni giuridiche che sottraggono appunto il cittadino alla logica mercantile?

${ }^{67}$ RODOTÁ, Stefano. Il terribile diritto, p. 23. No original: Se le risposte scelgono la seconda alternativa, non solo il ruolo della proprietà nel sistema risulta quantitativamente ridimensionato. Può mutarne pure la qualità, perqué diventa più radicale lo sciogliersi del nesso proprietà-personalità.

${ }^{68}$ RODOTÁ, Stefano. Il terribile diritto, p. 23. No original: Diventa pure evidente il limite di una impostazione tutta risolta nella questione redistributiva. Il rapporto tra individuo e beni non è necessariamente mediato dalla logica proprietaria. 
fundamentais do gênero - a condição de direito subjetivo coletivo, a mudança de paradigma para sua proteção será radical. Porque tais direitos saem da exclusividade do público estatal e seu poder de polícia, em que dependem do voluntarismo autocrático do poder público, e passam à condição de bens autônomos, separados do individual e do público. Resgata-se a efetividade da função social e cria-se um novo modelo de tutela, a coletiva; um e outro objeto de futuras pesquisas.

\section{Conclusão}

Resumindo, a propriedade pós-moderna é um salto qualitativo em relação à propriedade dos códigos e da modernidade. No plano político, surge e se exerce no seio da república participativa; no plano jurídico caracteriza-se como propriedade especial constitucional; e perante o Código Civil, substitui a velha propriedade comum imobiliária, no plano concreto. ${ }^{69}$ Hoje, toda propriedade que o leitor possa ter ou obter, é propriedade da categoria especial: urbana ou rural ou étnica ou intelectual. Mas a categoria mais notável é a da propriedade coletiva propriamente dita, extrapatrimonial, como o ambiente, que em sua autonomia de bem coletivo constitui a base da função social.

\section{Referências}

BORGES, Roxana Cardoso Brasileiro. Função ambiental da propriedade rural. São Paulo: LTr,1999.

BRASIL. Artigos, pareceres, memoriais e petições: o decreto $\mathrm{n}^{\circ}$ 4.887/2003 e a regulamentação das terras dos remanescentes das comunidades dos quilombos. Disponível em: $<$ http://.www.planalto.gov. br/ccivil_03/revista/Rev_68/Artigos/Art_Maria.htm>. Acesso em: $24 \mathrm{fev}$. 2008.

${ }^{69}$ Cumpre ressalvar o caso da propriedade móvel corpórea, que não sofre impacto tão radical como a propriedade imóvel. Na pós-modernidade, os princípios e regras do Código Civil atuam como direito comum, pois predominam as propriedades especiais. 
BRASIL, Ministério da Ciência e Tecnologia. Efeito estufa e a convenção sobre a mudança do clima. Disponível em: <www.dominiopublico.gov. br>. Acesso em: 30 jan. 2008.

DIAS, Maria da Graça dos Santos. Direito e Pós-modernidade. In: DIAS, M. G. S; MELO, O. F; SILVA, M.M. Política jurídica e pósmodernidade. Florianópolis: Conceito, 2009, p. 11-34.

ENGELS, Friedrich. A origem da família, da propriedade privada e do Estado. Tradução de Leandro Konder. 14. ed. Rio de Janeiro: Bertrand Brasil, 1997.

FARIA, Ernesto. Dicionário escolar latino-português. 4. ed. Brasília: Ministério da Educação e Cultura, 1967.

FELTRIN, Diego. Comunidade caiçara. Disponível em: $<$ http:// equipedesocioogia.wordpress.com/category/uncategorized/>. Acesso em: 15 nov. 2009.

FERREIRA, Lourdes M. et al. Roteiro metodológico para elaboração de Plano de Manejo para Reservas Particulares do Patrimônio Natural. Brasília: IBAMA, 2004. Disponível em: <www.ibama.gov.br>. Acesso em: 25 fev. 2008.

FERREIRA, Pinto. Curso de direito agrário. São Paulo: Saraiva, 1994. FOUCAULT, Michel. A verdade e as formas jurídicas. Tradução de Roberto Cabral de melo Machado e Eduardo Jardim Morais. Rio de Janeiro: Nau, 1999.

GROSSI, Paolo. La propiedad e las propiedades: un análisis histórico. Traducción de Angel M. López y López. Madri: Civitas, 1992.

HOBBES, Thomas. Leviatã: ou a matéria, forma e poder de um estado eclesiástico e civil. Tradução de Rosina D’Angina. São Paulo: Ícone, 2000 .

LOCKE, John. Tratado sobre o governo civil. Tradução de Renato Janine Ribeiro. São Paulo: Martins Fontes, 1998.

MACKELDEY, F. Elementos del derecho romano. 4. ed. Madri: L. López, 1886. 
MARX, K; ENGELS, F. Manifesto do partido comunista. Tradução de Pietro Nassetti. São Paulo: Martin Claret, 2003.

MEIRELLES, Hely Lopes. Direito administrativo brasileiro. 24. ed. São Paulo: RT, 1999.

MELLO, Celso Antônio Bandeira de. Curso de direito administrativo. 12. ed. São Paulo: Malheiros, 2000.

NABAIS, José Casalta. Alguns perfis da propriedade coletiva nos países do Civil Law. Coimbra: Coimbra, [1998].

NEIVERTH, Nayme; SAHR, Cicilian Luiza Löwen. Ações governamentais na Comunidade Faxinalense Taquari dos Ribeiros (Rio Azul/PR). Disponível em: <http://www.uepg.br>. Acesso em: 15 nov. 2009

Faxinalense Taquari dos Ribeiros (Rio Azul/PR). Disponível em: $<$ http:// www.uepg.br>. Acesso em: 15 nov. 2009.

PEREIRA, Ascísio dos Reis. A moral liberal como processo educativo no pensamento político de John Locke. In: CANDIDO, Celso; CARBONARA, Vanderlei. Filosofia e ensino: um diálogo transdisciplinar. Ijuí: Unijuí, 2004, p. 153-167. Disponível em: <www. espaçoacademico.com.br >. Acesso em: 20 abr. 2009.

POVOS E COMUNIDADES tradicionais realizam $2^{\circ}$ Encontro Estadual em Faxinal. Disponível em: <http://equipedesocioogia.wordpress.com>. Acesso em: 15 nov. 2009.

RAMOS, J. Arias. Derecho romano: parte general, derechos reales. 7. ed. Madri: Editorial Revista de Derecho Privado, 1958.

REALE, Miguel. Introdução à filosofia. São Paulo: Saraiva, 1994.

ROCHA, Maria E. Guimarães. O Decreto n ${ }^{\circ} 4.887 / 2003$ e a regulamentação das terras dos remanescentes das comunidades de quilombos. Disponível em: <www.presidencia.gov.br>. Acesso em: 22 jun. 2007.

RODOTÁ, Stefano. Il terribile diritto: studi sulla proprietà privada.

Bolonha: Il Mulino, 1990. 
RUGGIERO, Roberto de. Instituições de direito civil. Tradução de Paolo Capitanio. Campinas: Bookseller, 1999, v. 2-3.

RUSSO, Eduardo Angel. Teoria general del derecho: en la modernidad y en la posmodernidad. Buenos Aires: Abeledo-Perrot, [1995].

SAVIGNY, Friedrich Karl Von. Metodologia jurídica. Tradução de Heloísa da Graça Buratti. São Paulo: Rideel, 2005.

TAFARO, Sebastiano. La herencia de los tribuni plebis. Traducido por Carla Amans. Buenos Aires [2008], digit.

WOLKMER, Antônio Carlos (Org.). Pluralidade jurídica na América Luso-Hispânica. Porto Alegre: Livraria do Advogado, 1998. 